\title{
IMPLEMENTASI ALAT BANTU PERTANIAN MAN-TOOLS DI DESA TEJAMULYA UNIVERSITAS MAJALENGKA
}

\author{
Ardi Mardiana*, Enang Rusnandi, Deffy Susanti \\ Informatika, Universitas Majalengka \\ *aim@unma.ac.id
}

\begin{abstract}
In the agricultural sector, the role of tools, the grouping of agricultural tolls and machines cannot be separated from the definition of the tools and machines can be distinguished from the general case because a machine can be driven by human power or automatically. Reflecting on the modern agricultural system that has been implemented in developed countries, such as Japan, America, and China. The pattern of agriculture in Indonesia must immediately improve. The reason is that most farmers in Indonesia have not been able to maximize the development of tools, technology and utilize modern agricultural tools to boost the productivity of the rice fields.
\end{abstract}

Keywords: agricultural tools; agricultural modern tools

\begin{abstract}
Abstrak
Dalam sektor pertanian tak luput daripada peranan alat, pengelompokan alat dan mesin pertanian tidak lepas dari definisi alat itu sendiri. Perbedaan mendasar antara alat dan mesin dapat di bedakan dari hal yang umum karena sebuah mesin memiliki poros sedangkan alat tidak, sehingga mesin bisa saja digerakan dengan tenaga manusia maupun secara otomatis. Desa Tejamulya, Kecamatan Argapura merupakan desa yang perekonomiannya berfokus dari sektor pertanian bawang dengan luas lahan terbesar di Jawa Barat, namun dalam proses bertani masih alat dan metode tradisional yang tentunya tidak efisien tenaga dan waktu. Tujuan dari rancang bangun alat ini adalah untuk mengembangkan teknologi untuk memudahkan dalam proses penanaman bibit bawang, mencabut bawang, dan membersihkan lahan dari hama rumput liar. Adapun kesimpulan dari kegiatan implementasi ini adalah dihasilkan dua alat pertanian modern. Masingmasing alat memiliki kegunaan berbeda, alat pertama untuk menanam bibit bawang, dan memindahkan bawang dari lahan satu ke lahan lain tanpa membungkukan badan. Alat kedua untuk membersihkan lahan dari rumput liar dengan posisi vertical maupun horizontal tanpa membungkukan badan yang dilengkapi dua mata pisau yang dapat digerakan dua arah pemotongan.
\end{abstract}

Kata Kunci: alat pertanian; alat pertanian modern

\begin{tabular}{l|l|l} 
Submitted: $2021-09-23$ & Revised: $2021-10-26$ & Accepted: 2021-10-30
\end{tabular}

\section{Pendahuluan}

Sektor pertanian mempunyai peranan yang sangat penting dalam membangun perekonomian nasional termasuk perekonomian daerah, karena sektor pertanian berfungsi sebagai penyedia bahan pangan untuk ketahanan pangan masyarakat, sebagai instrument pengentasan kemiskinan, penyedia lapangan kerja, serta sumber kehidupan.

Dalam sektor pertanian maka tak luput daripada peranan alat, pengelompokan alat dan mesin pertanian tidak lepas dari definisi alat itu sendiri. Perbedaan mendasar antara alat dan mesin dapat di bedakan dari hal yang umum karna sebuam mesin memiliki poros sedangkan alat tidak, sehingga mesin bisa saja digerakan dengan tenaga manusia maupun secara otomatis.

Berkaca dari sistem pertanian modern yang telah diterapkan di negara-negara maju, seperti Jepang, Amerika, dan China. Pola pertanian di Indonesia harus segera berbenah. Pasalnya, sebagian besar petani di Indonesia belum mampu memaksimalkan perkembangan alat, teknologi dan memanfaatkan alat-alat pertanian modern untuk mendongkrak produktivitas area persawahan.

Di Desa Tejamulya sebagai daerah yang memiliki kesuburan tanah, iklim, dan faktor-faktor yang mendukung sektor pertanian. Desa Tejamulya yang mayoritas penduduknya bertani bawang dan salah satu penghasil bawang terbesar di Jawa Barat, namun dalam proses bertani masih menggunakan alat serta metode yang masih tradisional, Dengan metode yang masih tradisional tentunya banyak yang mesti di korbankan oleh para petani dengan itu kami berinisiatif untuk membuat sebuah alat pertanian yang bernama Man-Tools. 


\section{Metode}

Penelitian ini dilakukan selama 20 hari, dari tanggal 27 September 2021, sampai 16 Oktober 2021. Adapun kegiatan perancangan dan pembuatan dua alat pertanian ini dilaksanakan di bengkel las sekitar Kecamatan Maja, Kabupaten Majalengka. Bahan-bahan yang digunakan dalam penelitian ini antara lain besi pipa ukuran diameter 3 inci panjang 3 meter 1 buah, plat strip panjang 1 meter 1 buah, besi pipa ukuran 6 inci panjang $20 \mathrm{~cm} 1$ buah, dan baut ukuran dua belas 4 buah.

Penelitian ini dilakukan melalui beberapa tahapan seperti berikut :

1. Tahap pertama yaitu tahap perancangan yang dimulai studi literatur, perancangan konsep alat, melakukan analisis rancangan dan pembuatan gambar sketsa.

2. Tahap kedua yaitu pengadaan bahan-bahan dan alat las untuk proses perakitan sesuai gambar sketsa.

3. Tahap ketiga yaitu tahap uji coba kedua alat Man-Tools dengan mencoba langsung di lahan pertanian bawang Desa Tejamulya bersama GAPOKTAN Desa Tejamulya. Selama uji coba, dilakukan pengamatan terhadap kinerja alat tersebut apakah produk hasil pembentukan sudah memenuhi dengan target yang dicapai. Bila belum memenuhi maka dilakukan penyetelan atau perbaikan hingga target yang ditentukan tercapai.

\section{Hasil dan Pembahasan}

Dari pelaksanaan penelitian ini telah dibuat 2 buah alat ngayuman, dan 2 buah alat ngored. Dari kedua alat tersebut fungsinya berbeda, fungsi alat ngayuman yaitu sebagai berikut :

1. Alat ini dapat digunakan sebagai alat untuk menanam benih tanaman

2. Lebih mudah digunakan tanpa harus membungkukan badan atau jongkok.

3. Dapat memindahkan tanaman dengan lebih mudah tanpa harus menggali tanah.

4. Alatnya simple mudah untuk dibawa.

5. Kuat dan tahan lama.

6. Harga lebih ekonomis.

7. Lebih aman untuk digunakan.

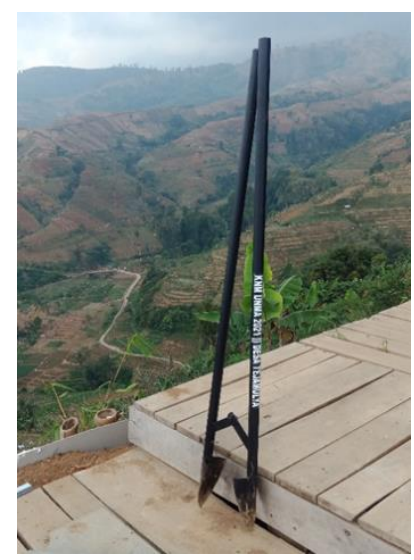

\section{Gambar 1 Hasil Rancang Bangun Alat Man-Tools (Ngayuman)}

Fungsi alat ngored yaitu sebagai berikut :

- Renggangkan alat agar matapisau melancip

- Tancapkan alat ke tanah sampai mata pisau terkubur tanah.

- Tutup kembali alat (posisi mata pisau masih terkubur tanah)

- Masukan benih yang akan ditanam.

- Cabut alat dan rapihkan kembali tanah. 
- Lakukan langkah tersebut secara berulang.

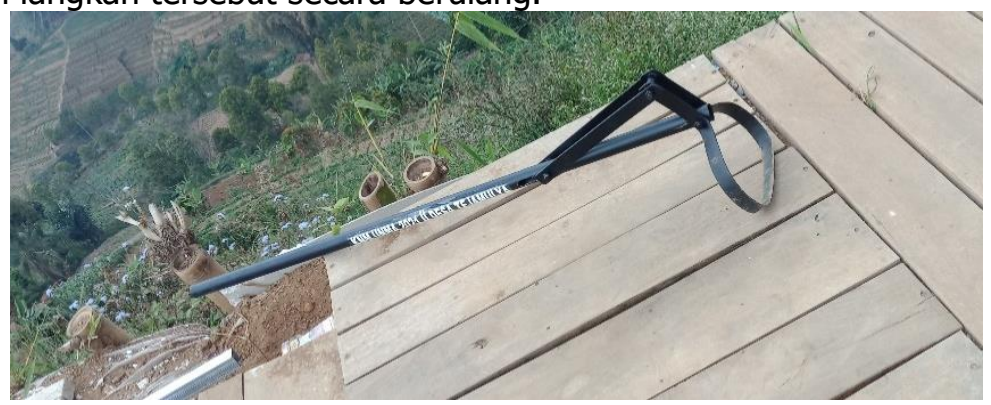

\section{Gambar 2 Hasil Rancang Bangun Alat Man-Tools (Ngored)}

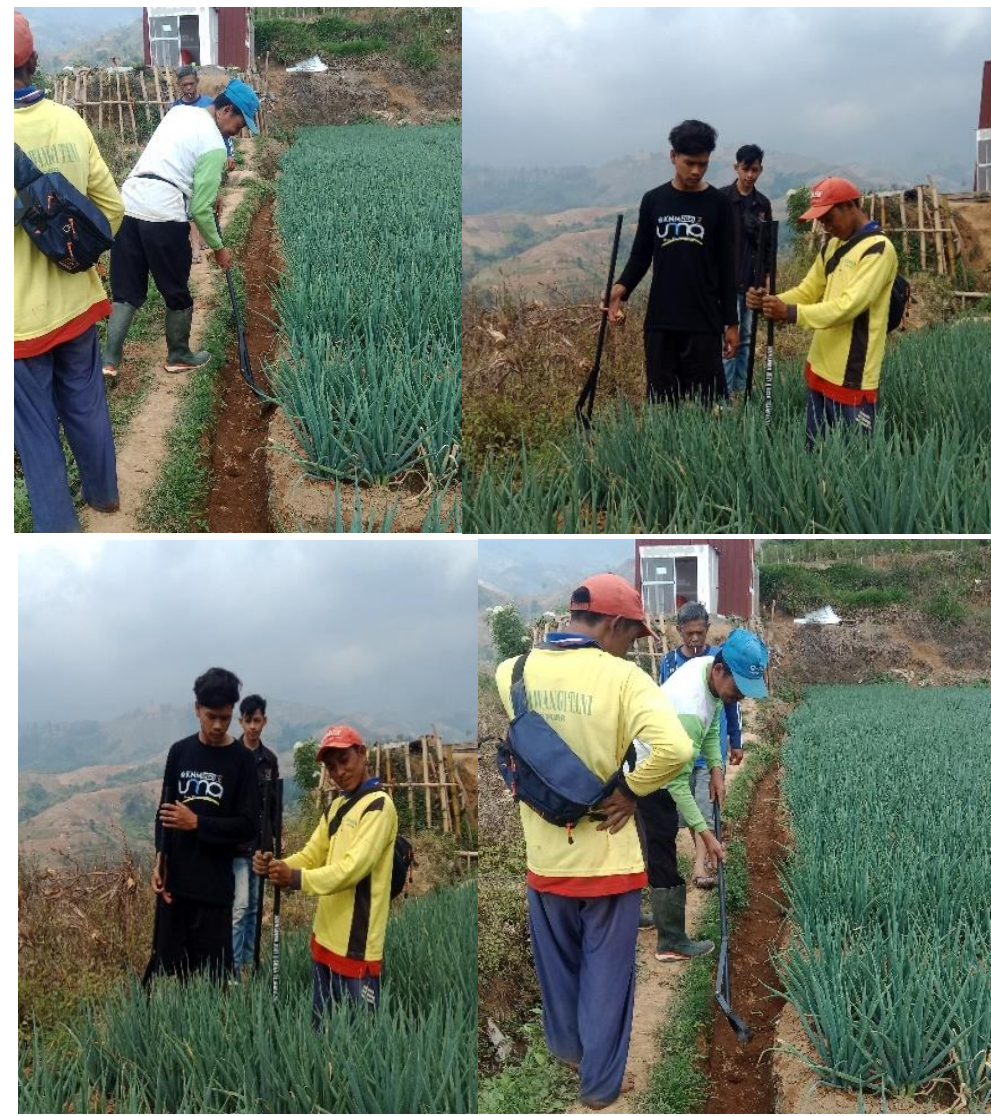

Gambar 3 Percobaan Alat Man-Tools Ke Petani

Gambar 3 merupakan salah satu rangkaian uji coba alat terhadap para petani dan sekaligus sosialisasi bagaimana metode penggunaan alat serta perangkaian alat. Dari rangkaian di atas didapatkan sebuah hasil perbandingan antara alat pertanian tradisional dengan alat man-tools seperti yang tertera pada table 1 .

Tabel 1. perbandingan alat pertanian tradisional dengan alat Man-Tools

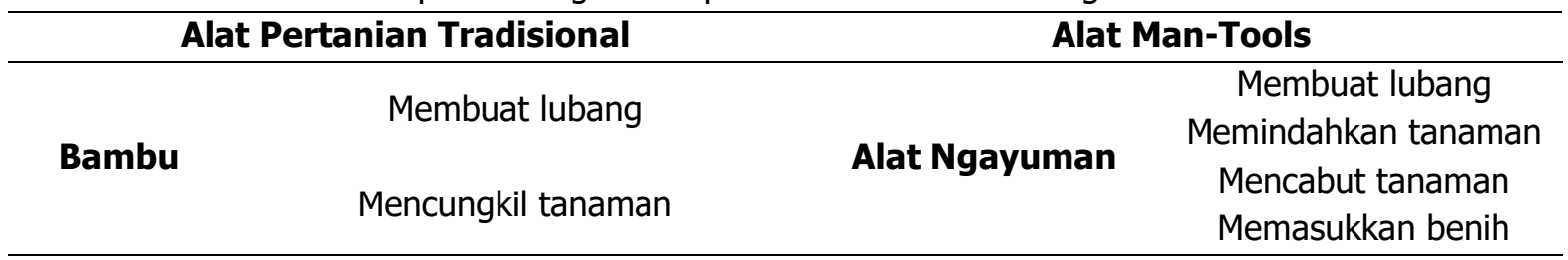


Digunakan sambil jongkok atau membugkuk

Memotong rumput

Menggemburkan tanah

Kored
Alat Ngored

\author{
Dapat di gunakan \\ sambil berdiri \\ Mencegah sakit \\ pinggang \\ Mencegah penyakit \\ lordosis \\ Memotong rumput \\ Memiliki 2 mata pisau \\ Proses pemotongan \\ cepat \\ Digunakan sambil \\ berdiri \\ Mencegah penyakit \\ lordosis \\ Mencegah sakit \\ pinggang
}

\section{Kesimpulan}

Dengan alat Man-Tools ini para petani sangat terbantu sekali pada saat melakukan proses pembersihan rumput liat beserta pada saat proses pengayuman dan juga mengatasi terjadinya sakit pinggang.

Diharapkan dengan ter implementasinya alat ini di masyarakat, masyarakat dapat mempergunakan alat ini dengan sebaik mungkin serta dari alat ini dapat meningkatkan kesejahteraan para petani di desa Tejamulya. Serta dari hadirnya alat ini di kemudian hari dapat lebih berkembang jadi lebih baik lagi.s

\section{Daftar Pustaka}

Asmara, Rangga. 2017. "Ekplorasi Leksikon Perkakas Pertanian Tradisional Jawa se- bagai Penguatan Konservasi Bahasa Ja- 10 Widyaparwa, Volume 47, Nomor 1, Juni 2019 wa". Prosiding Pertemuan Ilmiah Bahasa dan Sastra Indonesia (PIBSI) 39. Sema- rang: Universitas Diponegoro.

Aswiyati, Indah. 2015. "Perkembangan Petani Padi Sawah di Tondano Sebuah Tinjau- an Sejarah". Jurnal LPPM Bidang Eko- SosBudKum. Volume 2. Nomor 12015.

Manado: LP2M Universitas Sam Ratulangi. Budhiono, R. Hery. 2017. "Leksikon Alat dan Aktivitas Bertanam Padi dalam Bahasa Jawa". Jurnal Kandai, 13(2), 235-248.

Nurhayati. 2010. "Pengaruh Teknologi Mesin terhadap Perubahan Penggunaan Kosa Kata di Bidang Pertanian (Sebuah Kajian atas Masyarakat Petani di Kabupaten Blora)". Parole Journal of Lingu-istics and Education. Volume 1. Nomor 1 Oktober. Semarang: Universitas Diponegoro.

Nurmayanti, Indah, dkk. 2018. Fungsi Mesin Traktor dan Alat Tradisional Pengolah Tanah. https://doi.org/10.31219/osf.io/mywvc Prayitno dan Arsyad. 2009. Petani Pedesaan dan Kemiskinan. Yogyakarta: Balai Pertanian Fakultas Ekonomi. Sudaryanto. 1988. Metode Linguistik. Bag. I: Ke Arah Memahami Metode Linguistik. Yog- yakarta: Gadjah Mada University Press.

Wahya; Djajasudarma, Fatimah; dan Citrares- mana, Elvi. 2017. "Istilah Alat Teknologi Tradisional Pertanian Sawah Sunda Wuluku 'Bajak' dan Persebarannya secara Geografis (Sundanese Term Wuluku 'Plow' in Rice Farming Traditional Tech- nology and its Geographical Spread)". Jurnal Sosioteknologi. Volume 16. Nomor 2 Agustus. Bandung: Insitut Teknologi Bandung. 
Wahyuni, Tri. 2017. "Makna Kultural pada Istilah Bidang Pertanian Padi di Desa Boja Kabupaten Kendal Jawa Tengah (Sebu- ah Tinjauan Etnolinguistik)". Jurnal Jala- bahasa, 13(1), 20-30.

Wardani, Gayatri Kumala. 2012. "Peralatan Pertanian Padi Tradisional di Kabupaten Magetan: Kajian Semantik". Skripsi. Yogyakarta: Jurusan Pendidikan Bahasa Daerah, Fakultas Bahasa dan Seni, Uni- versitas Negeri Yogyakarta. 